\title{
An Answer I Don't Know I Know
}

\section{Sydney Dosser}

Mohawk College

My name is Sydney Dosser, and I am 21 years old. I am currently in my third year of moving through different postsecondary programs, trying to learn what I want my future to look like. When I think of the word 'future,' first I think of my past. I feared the future because I knew it would bring disruption and loss. I knew I had to change myself to meet it - to grow up, take responsibility for my whole life, and find whatever ending I was supposed to reach. But the future is not the culmination of an individual life, or something you can watch arrive. The future simply does not exist. All we have is the constant progression of the present, a slight idea of what may come next, and the memories of what used to be the present. Time is a collective experience. It is just the next present, the next decision, the next change. It is owned by no one and it involves everyone. What I express in my poem is that chasing a nebulous future will leave you empty and confused. The present is all we have, and we face it and change it together.
Keywords

poetry, existential, anxiety, uncertainty, hope 


\section{My Future is Not Mine}

\section{Cassandra Sukraj}

My name is Cassandra Sukraj and I'm 18 years old from Toronto. I am currently a first-year postsecondary student, slowly building my artistic career alongside my academics. This includes focusing on my passion for poetry as well as graphic design. My piece in this journal, My Future is not Mine, expresses the way I envision my future I pretty much don't. I feel that it is mostly unpredictable and essentially none of my business. Of course I still plan and create goals for the future, however I understand that they are always subject to change and I tend to leave nearly everything for 'future Cassandra.' I've learned to trust and reassure myself that things will always work out, and therefore I simply envision my future as whatever I will want it to be when the time comes. My values and dreams continue to change as I grow and mature, so although I cannot paint a picture of the future as of yet, I know it will be exactly what I want it to be.
Keywords

future, poetry, depression, change, trust 
Again and again,

I find myself looking,

for some kind of affirmation.

A definite fact

that says

Yes, you are a good person.

Because more and more

I come to conclusions

about my own value

in life and in time,

only to lose them again deep inside

an ocean of thought and emotion,

my logic and creativity alike

slipping away like sand through my fingers, as a whipping wind throws my hair

and throws my peace

away into a vast horizon.

I'm never okay with not knowing.

Some things I need to be certain of.

And a future is hidden in overbearing mist

bothers me.

How am I supposed to find the right way

when I can't see where I'm going?

How am I supposed to deserve my life?

It's all set up for me, so 
shouldn't I be feeling perfect?

But gratitude at this point

feels like a cruel taunt

in a world where no one really gets

all that they deserve.

But I'm included when I know that we all deserve to live and I deserve as many tries

as it takes

to find my answer,

or to realize that I don't need one.

I'm a part of it all

and maybe I don't need to know

the true scope of what that means.

Maybe it really is enough

to keep on making decisions

that make life on Earth

just a little bit better

for a little part

of someone's little life.

Because little is relative

when we really are a speck

in the millennia of the universe,

yet every move we make

sends ripples

in reactive time,

an interactive world,

in which none of us choose to be born 
but we choose to stay

and we choose to keep choosing.

I don't know why I have so much fear

of locking myself into a future

when I have - no, I AM the key.

Because really,

the future doesn't exist.

And today

is yesterday's future.

It's now

and I'm here to be alive,

to interact,

in the infinity of the present. 